\title{
Synthesis of Quinoxaline Derivatives at Room Temperature Using Magnetic Material Separated from Coal Fly Ash
}

\author{
Aashish O. Dhokte, Mahadeo A. Sakhare, Machhindra K. Lande, and Balasaheb R. Arbad* \\ Department of Chemistry, Dr. Babasaheb Ambedkar Marathwada University, Aurangabad (M.S.), 431004, India. \\ ${ }^{*}$ E-mail: abrchem9@gmail.com
}

(Received November 6, 2012; Accepted December 13, 2012)

\begin{abstract}
An efficient synthesis of quinoxalines derivatives is described using magnetic material separated from coal fly ash. Coal fly ash is a waste material generated in huge amount by burning of coal for the generation of electricity in thermal power station. It contains $\mathrm{SiO}_{2}, \mathrm{Al}_{2} \mathrm{O}_{3}$ and magnetic material in significant amounts, from which magnetic material was separated by using magnetic separation method. These separated magnetic material further characterized by XPS, XRD, EDS, FTIR, SEM, TEM and BET techniques. The merits of present method are mild reaction conditions, and also excellent yields and short reaction times.
\end{abstract}

Key words: Fly ash, Quinoxaline, Room temperature, Cyclocondensation

\section{INTRODUCTION}

The methodology for the synthesis of heterocyclic compounds represents a powerful approach for rapid building of molecular complexity from potentially simple starting materials. ${ }^{1}$ Nitrogen containing heterocyclics are abundant in nature and exhibit diverse and important biological properties. ${ }^{2}$ Quinoxaline derivatives are an important class of nitrogen-containing heterocyclics and known to exhibit a wide range of biological activities including anticancer, $^{3}$ antiviral $^{4}$ and antibacterial..$^{5}$ Also these moieties have been found an applications in dyes, ${ }^{6}$ as building blocks in the synthesis of organic semiconductors, ${ }^{7}$ chemically controllable switches ${ }^{8}$ dehydroannulenes ${ }^{9}$ anti-inflammatory, anti-protozoal and anti-HIV, ${ }^{10,11}$ beside, these are also used in the agriculture field as fungicides, herbicides and insecticides. ${ }^{12}$ A number of synthetic strategies have been reported for the synthesis of quinoxaline derivatives., ${ }^{2,13}$ The most common method in which 1,2-dicarbonyl compound in acetic acid is refluxing for $2-12 \mathrm{~h}$ giving $34-85 \%$ yield $^{14}$ or in high boiling point solvent such as dimethylsulfoxide (DMSO) ${ }^{15}$ in the presence of catalytic amounts of molecular iodine. Improved methods have been developed for the synthesis of quinoxaline derivatives including the Bi-catalyzed oxidative coupling of epoxides and ene-1,2-di-amines, ${ }^{16}$ a microwave procedure, ${ }^{17} \mathrm{MnO}_{2},{ }^{18}$ Cerium ammonium nitrate ${ }^{19} \mathrm{CuSO}_{4} .5 \mathrm{H}_{2} \mathrm{O},{ }^{20}$ Montmorillonite $\mathrm{K}-10,{ }^{21}$ polyanilinesulphate salt. ${ }^{22}$ However, some of these methods suffer from one or more drawbacks, such as long reaction times, low yields, harsh reaction conditions and tedious work up procedure, therefore, development of an efficient and versatile method is still required.

Coal fly ash is waste product of coal combustion processes in a coal - fired thermal power stations. Large quantities of coal fly ash are produced in electric power plants throughout the world every year. The amount of coal fly ash formed is approximately 500 million tones per year and likely to increase. The global recycling rate of fly ash is only $15 \%{ }^{23}$ It is being consumed in the production of constructions materials, in agriculture, metal recovery, in water and atmospheric pollution control, etc. ${ }^{24}$ These applications could successful up to some extent to consume part of the huge amount of fly ash. Nevertheless, the search of new applications of the fly ash as either catalyst or as catalyst support material is still ongoing. Literature survey reveals that the fly ash is used as adsorption catalyst for the removal of dyes, ${ }^{25}$ heavy metals, ${ }^{26}$ etc. Major constituents of coal fly ash are $\mathrm{SiO}_{2}, \mathrm{Al}_{2} \mathrm{O}_{3}$ and $\mathrm{Fe}_{2} \mathrm{O}_{3}, \mathrm{Fe}_{3} \mathrm{O}_{4}$. After high temperature combustion, these oxides are formed with high thermal stability. Utilization of fly ash for other industrial applications provides a cost effective and environmentally benign way of recycling this solid waste. Currently researchers have focused on how to improve the capability of fly ash through proper beneficiation techniques in order to increase its catalytic activity. Literature survey reports the catalytic role of activated or modified fly ash for different reactions such as oxidation, ${ }^{27}$ dechlorination, ${ }^{28}$ condensation and rearrangement reactions. ${ }^{29}$ Fly ash is chemically activated by acid and used for esterification ${ }^{30}$ etc. Separation of magnetic material from fly ash is carried out by using magnetic separatiom method. Magnetic nanoparticles represent a set of unique building blocks 


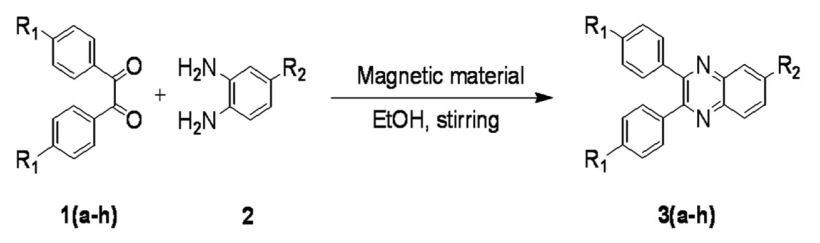

Scheme 1. Synthesis of quinoxaline derivatives using magnetic material as catalyst.

whose size and composition are tunable to meet the requirements for a range of applications including magnetic fluids, catalysis, data storage, biomedicine, and toxic waste remediation. ${ }^{31}$ The most common methods used to prepare ferrite complex oxides are co-precipitation, sol-gel method, micro-emulsion, etc. However, major drawback of these required precursors is the high starting costs of the raw materials that results in high production cost and also traditional process. To overcome these difficulties, the best alternative source is the coal fly ash which is the waste product of coal combustion in thermal power station. In the present work, separated magnetic material is characterized and used as catalyst for a simple, selective and environmentally acceptable synthesis of quinoxaline derivatives via two component reaction 1,2-diamine and benzyl (Scheme 1).

\section{EXPERIMENTAL}

\section{Materials}

The coal fly ash was obtained from thermal power station, Parli-Vaijnath, District-Beed, Maharashtra state, India. Other chemicals used were of synthesis grade reagents (Merck) and used as such, without further purification.

\section{Isolation of Magnetic Material from Fly Ash}

The coal fly ash slurry was prepared in clean $500 \mathrm{~mL}$ beaker by mixing coal fly ash with deionized water in 1:6 $\mathrm{Wt} / \mathrm{Vol}$ ratio. The slurry was stirred magnetically using magnetic stir bar for 20-30 minutes, during stirring the magnetic material present in the slurry was attached on the surface of magnetic stir-bar, which was removed and collected several times till the magnetic material was separated completely, which was then dried in an oven at $120^{\circ} \mathrm{C}$ for $2 \mathrm{~h}$ and used as catalytic material.

Fig. 1. shows Photographs of a) coal fly ash and b) isolated magnetic material from fly ash.

\section{Catalyst Characterization}

The X-ray diffraction (XRD) patterns of catalysts were recorded on a Bruker D8 advance X-ray diffractometer

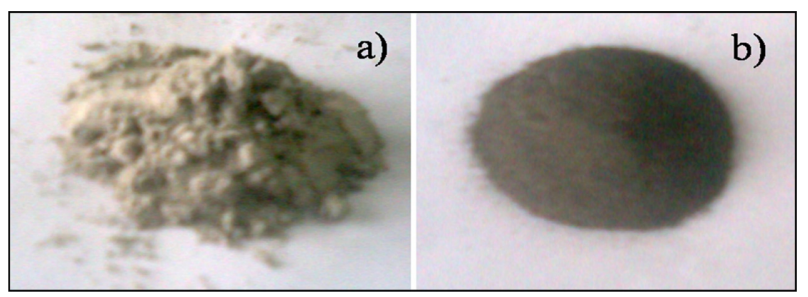

Fig. 1. Photographs of a) coal fly ash b) isolated magnetic material from fly ash.

using $\mathrm{Cu}-\mathrm{K} \alpha$ radiation with a wavelength of $1.540 \AA$. Infrared (FT-IR) spectra were recorded on a FT-IR spectrometer (JASCO, FT-IR, Japan) using dry $\mathrm{KBr}$ as a standard reference in the range of $500-4000 \mathrm{~cm}^{-1}$. The scanning electron microscopic (SEM) analyses were carried out with a JEOL JSM-6330 LA operated at $20.0 \mathrm{kV}$ and $1.0 \mathrm{nA}$. The elemental composition of the metal in the fresh fly ash and in magnetic material was estimated using an energy dispersive spectrophotometer (EDS). Brunnauer Emmett-Teller (BET) surface area was carried out on Quanta chrome CHEMBET 3000. X-ray photoelectron spectroscopy (XPS, ESCA3000-VG, Uckfield, UK) was used to study the chemical composition of the sample. The morphology of material was also characterized with CM-200 PHILIPS transmission electron microscopy (TEM) operated at $200 \mathrm{kV}$ and resolution, $0.23 \mathrm{~nm} .{ }^{1} \mathrm{H}$ NMR spectra of quinoxaline derivatives were recorded on an $300 \mathrm{MHz}$ FT-NMR spectrometer in $\mathrm{CDCl}_{3}$ as a solvent and chemical shifts values $\delta$ (ppm) are recorded relative to tetramethylsilane $\left(\mathrm{Me}_{4} \mathrm{Si}\right)$ as an internal standard.

\section{Reaction Procedure for Synthesis of Quinoxaline Deriv- atives}

A mixture of 1,2-diamine ( $5 \mathrm{mmol})$, benzil $(5 \mathrm{mmol})$ and catalytic amount of magnetic material $(0.1 \mathrm{~g})$ and ethanol $(10 \mathrm{~mL})$ was taken in round bottle flask and mechanically stirred for $3-5 \mathrm{~min}$. The reaction progress was monitored using TLC (hexane/ethylacetate (7:3)). When the reaction was complete as indicated by TLC, the reaction mixture was poured on crushed ice. The obtained product was washed with deionized water dried and recrystallized from ethanol to afford pure product.

\section{Spectroscopic Data of Compound}

2,3-diphenylquinoxaline (3a): IR ( $\mathrm{KBr}) v_{\max } / \mathrm{cm}^{-1} 3057$, $1602,1442,1346,1246,852,767,698 ;{ }^{1} \mathrm{H}$ NMR $\left(\mathrm{CDCl}_{3}\right.$, $300 \mathrm{MHz}): \delta 8.18(\mathrm{~m}, 2 \mathrm{H}), 7.78(\mathrm{~m}, 2 \mathrm{H}), 7.48(\mathrm{~m}, 4 \mathrm{H})$, $7.34(\mathrm{~m}, 6 \mathrm{H})$.

6-nitro-2,3-diphenylquinoxaline (3b): $\mathrm{IR}(\mathrm{KBr}) v_{\max } / \mathrm{cm}^{-1}$ 
$3439,3063,1614,1521,1446,1340,1246,850,767,698$; ${ }^{1} \mathrm{H} \mathrm{NMR}\left(\mathrm{CDCl}_{3}, 300 \mathrm{MHz}\right): \delta 9.08(\mathrm{~s}, 1 \mathrm{H}), 8.54(\mathrm{~d}, 1 \mathrm{H})$, $8.31(\mathrm{~d}, 1 \mathrm{H}), 7.66(\mathrm{~m}, 4 \mathrm{H}) 7.52(\mathrm{~m}, 4 \mathrm{H}), 7.40(\mathrm{~m}, 2 \mathrm{H})$.

\section{RESULTS AND DISCUSSION}

\section{EDS Analysis}

Fresh fly ash and magnetic material was analyzed qualitatively and quantitatively by EDS method are shown in (Table 1). Magnetically isolated material contains an increased amount of iron (33.86\%) as compared to fresh fly ash $(4.72 \%)$.

\section{XRD Analysis}

$\mathrm{X}$-ray diffraction analysis was performed to understand the morphological nature of the fly ash and magnetic material. (Fig. 2a) shows the XRD pattern for fresh fly ash. It is found that all the reflection peaks at $2 \theta=16^{\circ}, 20.8^{\circ}$, $23.2^{\circ}, 26.3^{\circ}, 30.5^{\circ}, 33.1^{\circ}, 36.1^{\circ}, 39.2^{\circ}, 40.7^{\circ}, 42.3^{\circ}, 45.6^{\circ}$, $50^{\circ}, 51.9^{\circ}, 54.5^{\circ}, 57.4^{\circ}$ and $59.8^{\circ}$ corresponds to the $(011)$,

Table 1. Chemical composition of fresh fly ash and magnetic material

\begin{tabular}{cccc}
\hline Sr. No. & Elements & $\begin{array}{c}\text { Mass \% of } \\
\text { Fresh fly ash }\end{array}$ & $\begin{array}{c}\text { Mass \% of } \\
\text { Magnetic material }\end{array}$ \\
\hline 1 & $\mathrm{O}$ & 46.98 & 34.07 \\
2 & $\mathrm{Na}$ & 0.25 & 0.54 \\
3 & $\mathrm{Al}$ & 15.08 & 10.92 \\
4 & $\mathrm{Si}$ & 28.12 & 20.61 \\
5 & $\mathrm{Fe}$ & 4.72 & 33.86 \\
6 & $\mathrm{Ca}$ & 2.18 & - \\
7 & $\mathrm{~K}$ & 0.94 & - \\
8 & $\mathrm{Mg}$ & 0.48 & - \\
9 & $\mathrm{Ti}$ & 1.25 & - \\
10 & Total & 100 & 100 \\
\hline
\end{tabular}

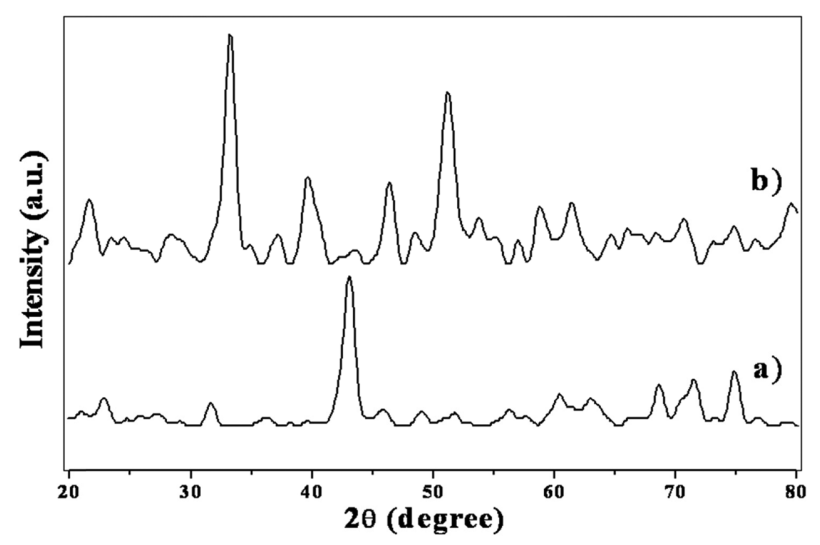

Fig. 2. X-ray diffraction pattern of a) fresh fly ash b) magnetic material.
(-111), (-101), (021), (111), (-131), (030), (-230) (-231) $(-222),(-240),(-124),(-233)(-250),(015)$ and $(-311)$ planes and which indicates the crystalline monoclinic nature of fresh fly ash (JCPDS No. 860680) and lattice parameter $\mathrm{a}=5.0 \mathrm{~b}=8.6 \mathrm{c}=8.2 \AA$. Whereas (Fig. 2b) shows the XRD pattern for magnetic material and It was found that the sharp reflection peaks at $2 \theta=33.2^{\circ}, 39.3^{\circ}, 46.2^{\circ}$, $65.8^{\circ}, 75.2^{\circ}, 79.4^{\circ}, 91.4^{\circ}, 107.8^{\circ}, 111.5^{\circ}$ and $138.4^{\circ}$ corresponds to the (104), (006), (007), (118), (217), (1110), (402), (407), (413) and (420) planes which indicates highly crystalline hexagonal structure of ferrite type material (JCPDS No. 860550) and $\mathrm{a}=\mathrm{b}=5.035 \mathrm{c}=13.74 \AA$.

\section{Crystallite Size Determination}

The crystalline nature and the crystallite size of the sample was analyzed by X-ray diffeaction data. The particle size of the material plays an important role in determining the reactivity of fresh coal fly ash and isolated magnetic material. It was observed that the particles with smaller size exhibited higher reactivity due to availability of higher specific surface area. ${ }^{32}$ Generally, the crystallite size was estimated by Debye-Scherrer equation $(T=0.94 \lambda / \beta \cos \theta),{ }^{33}$ where $T$ is the particle size, $\lambda$ is the wavelength, $\theta$ is the diffraction angle and $\beta$ is (FWHM). The mean crystallites size of fresh fly ash is $50 \mathrm{~nm}$ and magnetic material is $10 \mathrm{~nm}$.

\section{XPS Analysis}

Although the XRD pattern of the samples (Fig. 2b) clearly show the hexagonal structure, it is very difficult to exclude the possibility of the $\gamma-\mathrm{Fe}_{2} \mathrm{O}_{3}$ phase in the separated magnetic $\mathrm{Fe}_{3} \mathrm{O}_{4}$ phase similarity. XPS is one of the most effective way to distinguish the two phases because it is very sensitive to $\mathrm{Fe}^{2+}$ and $\mathrm{Fe}^{3+}$ cations. In (Fig. 3c) the levels of $\mathrm{Fe} 2 \mathrm{p}_{3 / 2}$ and $\mathrm{Fe} 2 \mathrm{p}_{1 / 2}$ have binding energies 711 and $720 \mathrm{eV}$ respectively. It conform the presence of $\mathrm{Fe}_{3} \mathrm{O}_{4}$ phase, ${ }^{34,35}$ (Fig. 3b) shows binding energy of Si (2p) at $102.9 \mathrm{eV}$, and (Fig. 3a and d) shows absorption peaks of $\mathrm{Al}(2 \mathrm{p})$ and $\mathrm{O}(1 \mathrm{~s})$ are at 74.84 and $531.9 \mathrm{eV}$ respectively.

\section{TEM Analysis}

The TEM images (Fig. 4) shows the presence of small spherical particles. From TEM images, measured diameter of particles is $\sim 10 \mathrm{~nm}$, which is consistent with the results of XRD analysis. Electron diffraction pattern of magnetic material (Fig. 4d) reveals that the sample is polycrystalline, which can be indexed to the hexagonal structure of magnetic material and accord with the XRD result. TEM image also show that the magnetic material is roughly spherical in shape. Usually, spherical shapes are 

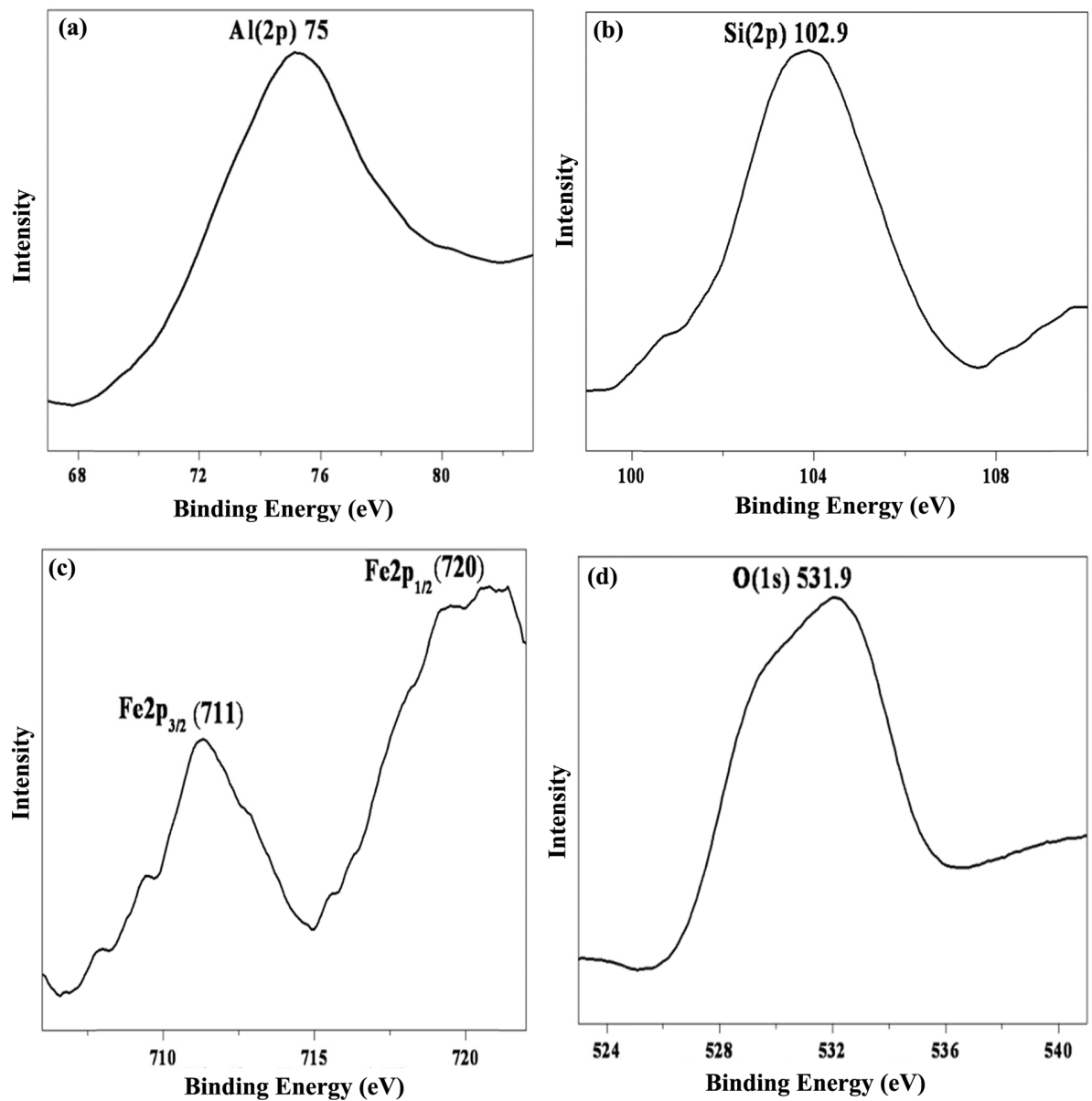

Fig. 3. High-resolution XPS spectra of magnetic material contains (a) Al (2p) XPS spectra, (b) Si (2p) XPS spectra, (c) Fe(2p) XPS spectra, and (d) O1s XPS spectra.
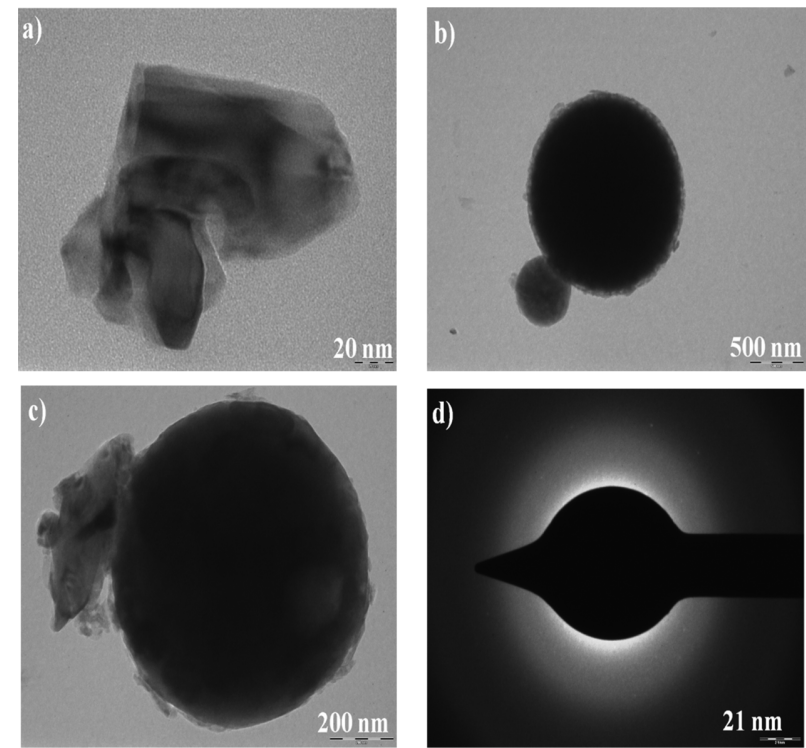

Fig. 4. TEM images (a, b, c) of magnetic material and (d) Diffraction pattern of magnetic material. formed because the nucleation rate, per unit area is isotopic at the interface between the $\mathrm{Fe}_{3} \mathrm{O}_{4}$ magnetic nanoparticles. ${ }^{34}$ Materials are magnetic in nature as well as nano-sized particles are known to have very large surface areas hence, catalytic material will also have high surface energy. Consequently, these fine spherical particles have coated with aluminum silicate network and form aggregated nano-particles. The dark iron center and white aluminum silicate surface of particles are visible.

\section{SEM Analysis}

Fig. 5a SEM image of fresh fly ash shows hollow cenospheres, irregularly shaped, mineral aggregates and agglomerated particles. Similar particles were also observed in other reported micrographs. ${ }^{31}$ SEM image of magnetic material (Fig. 5b) shows sub-angular and spherical particles, increase in spheriodal nature of the magnetic material due to the magnetic separation method. 

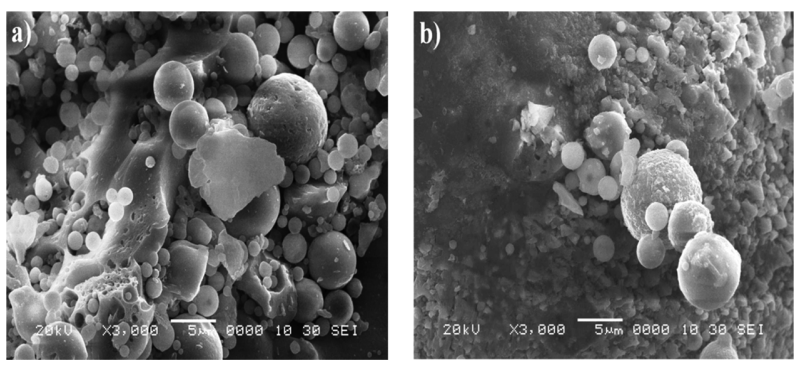

Fig. 5. SEM images of a) fresh fly ash b) magnetic material.

\section{BET Analysis}

The specific surface area of fresh fly ash and magnetic material are $1.6233 \mathrm{~m}^{2} / \mathrm{g}$ and $105 \mathrm{~m}^{2} / \mathrm{g}$ respectively. Thus magnetic material provided surface for reactant to adsorbed and decrease the time to convert reactant to desired product.

\section{FT-IR Analysis}

The FT-IR spectrum of fresh fly ash in (Fig. 6a) shows a broad band at $1060 \mathrm{~cm}^{-1}$ is attributed to $\mathrm{Si}-\mathrm{O}-\mathrm{Si}$ stretching vibrations. (Fig. 6b) shows the IR spectrum of magnetic material. The bands absorptions at 1078, 784, 560 $\mathrm{cm}^{-1}, 3437 \mathrm{~cm}^{-1}$ and $1634 \mathrm{~cm}^{-1}$. The $1078 \mathrm{~cm}^{-1}$ is due to the asymmetric stretching of $\mathrm{Si}-\mathrm{O}-\mathrm{Si}$ bands of the $\mathrm{SiO}_{4}$ tetrahedron. The $784 \mathrm{~cm}^{-1}$ band is composed of the contributions from $\mathrm{Si}-\mathrm{O}-\mathrm{H}$ and $\mathrm{Si}-\mathrm{O}-\mathrm{Fe}$ vibrations, and the band at $560 \mathrm{~cm}^{-1}$ is related with the $\mathrm{Fe}-\mathrm{O}$ stretching. ${ }^{36,37}$ The IR spectrum of magnetic material also shows a broad intense band at $3457 \mathrm{~cm}^{-1}$ due to hydroxyl groups on the catalyst surface and peak at $1634 \mathrm{Cm}^{-1}$ is attributed to bending mode $\left(\delta_{\mathrm{O}-\mathrm{H}}\right) \cdot{ }^{38} \mathrm{It}$ is assumed that during the process of burning of coal at high temperature there is conversion of $\mathrm{Fe}_{2} \mathrm{O}_{3}$ into $\mathrm{Fe}_{3} \mathrm{O}_{4}$ which may be coated around aluminosilicate framework. However, these peaks are absent in the FT-IR spectrum of the fresh fly ash (Fig. 6a) which do not posses any catalytic activity.

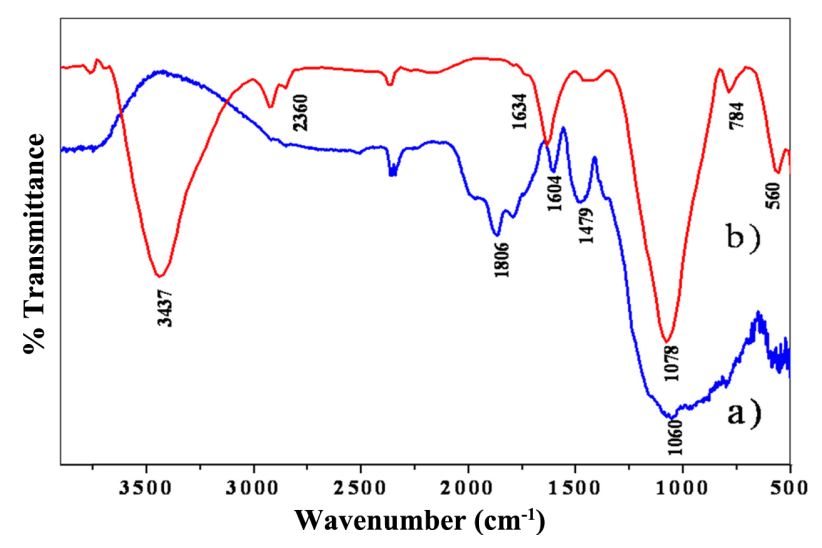

Fig. 6. The FT-IR spectra of a) fresh fly ash b) magnetic material.

\section{Study of Pyridine Adsorption}

The probe of our catalyst acidity and basicity was briefly elucidate by pyridine adsorption, which was carried out taking small amount of catalyst and evacuation was done at room temperature for $24 \mathrm{~h}$ and second at $150^{\circ} \mathrm{C}$ for $2 \mathrm{~h}$. FTIR spectrum of catalyst obtained with evacuation at room temperature (Fig. 7a) shows intensive bands at 1536 and $1444 \mathrm{~cm}^{-1}$ are indicating the presence of Brönsted and Lewis acid sites, respectively on catalyst surface, with which pyridine forms coordination bonds. ${ }^{39,40}$ However, a third band at $1482 \mathrm{~cm}^{-1}$ is widely believed to be the result of a combined contribution of Brönsted and Lewis acid sites. ${ }^{41}$ The spectrum also shows bands 3517, 3610 and $3710 \mathrm{~cm}^{-1}$ was due to present of bronsted acidic sites or hydroxyl group on catalyst surface. ${ }^{42,43}$ However spectrum (Fig. 7b) obtained after evacuation at $150{ }^{\circ} \mathrm{C}$ for $2 \mathrm{~h}$ the band $1536 \mathrm{~cm}^{-1}$ was disappeared and band $1631 \mathrm{~cm}^{-1}$ appear due to the presence of strong proton centers on the catalyst surface, with which pyridine molecules can interact with a creation of $\mathrm{Py} \mathrm{H}^{+} .{ }^{39-41}$ The spectrum also shows bands in region $3500-3700 \mathrm{~cm}^{-1}$ was due to present of bronsted acidic sites or hydroxyl group on catalyst surface. Pyridine adsorption study shows that catalyst posses both Lewis acidic sites and Bronsted acidic sites.

\section{Catalytic Activity Results}

The methodology of synthesis of quinoxaline derivatives is reported using very low amount of magnetic material for the reaction of 1:1 mole ratio of benzil and aromatic 1, 2-diamine in ethanol and mechanically stirred at room temperature (Scheme 1), and quantitative yield of the product was obtained in 3-5 min. The results of this synthetic method are found to be inspiring. In the similar manner, a variety of substituted quinoxaline derivatives were synthesized using various substituted benzil and aromatic 1,2-diamines (Table 3) to confirm the role of catalyst; however when the same reaction was carried out in the absence of catalyst, the desired product was not appeared even after $1 \mathrm{~h}$. It means that the catalyst plays a crucial role in the success of the reaction in terms of the rate and yield.

Industrial point of view, the role of catalyst is very important therefore we have studied the quinoxaline reaction at various mili mole of benzil and 1,2 diamine and observed that the yield of the desired product is in the range (94 to 90\%) (Fig. 8). While performing the laboratory scale reaction of quinoxaline synthesis using variable amount of catalyst, the reaction time and yield of the product remained nearly same, this indicates that if the reaction is to be carried out in large scale it is necessary to use the amount of 

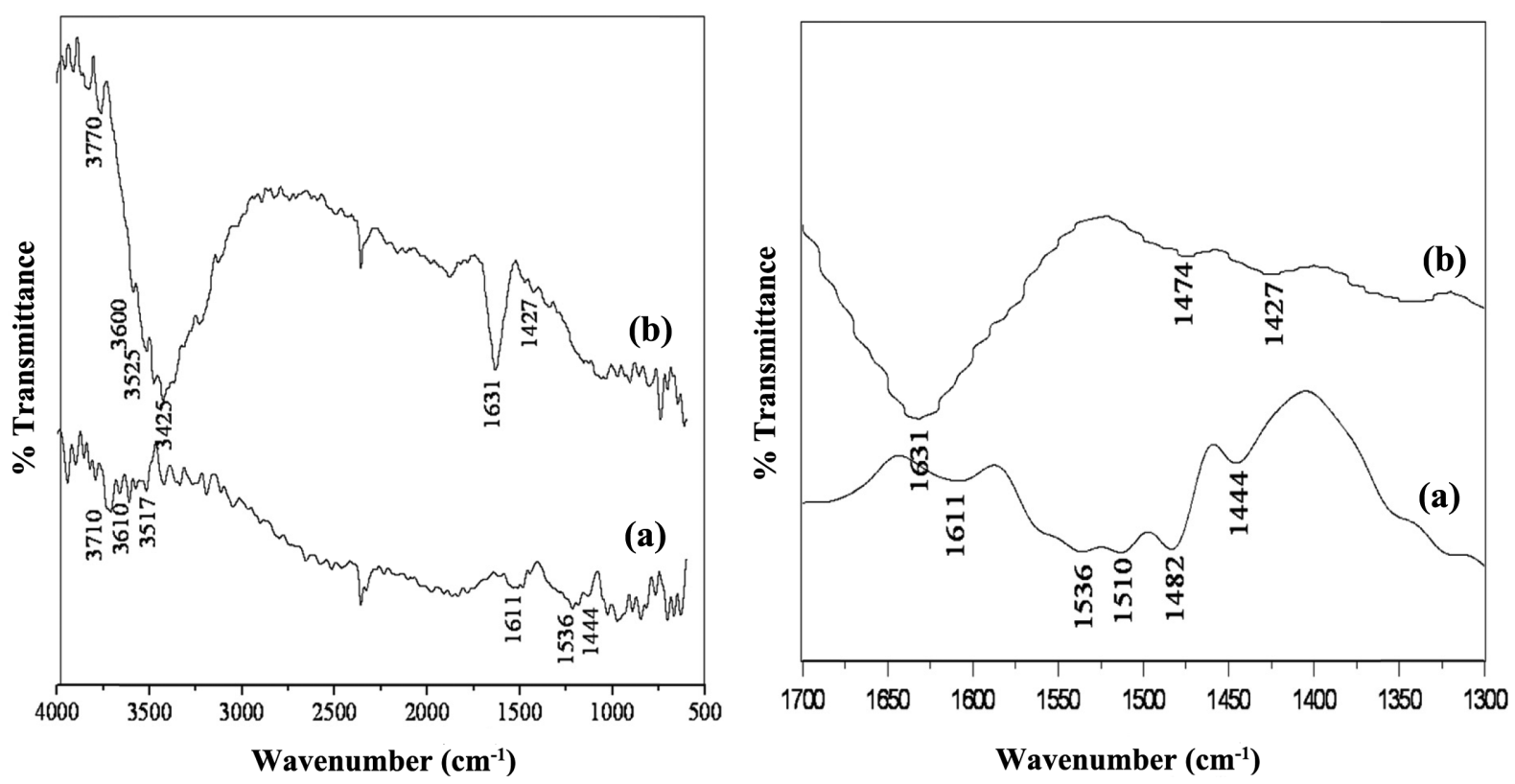

Fig. 7. FT-IR spectrum of pyridine adsorbed on the magnetic material a) at RT and b) at $150{ }^{\circ} \mathrm{C}$.

Table 2. Comparison of synthesis of quinoxaline with different catalysts

\begin{tabular}{cccccc}
\hline Entry & Catalyst & Solvent & Time (min) & Yield (\%) & Reference \\
\hline 1 & Mont.K-10 & water & 150 & 100 & 21 \\
1 & $\mathrm{CuSO}_{4} \cdot 5 \mathrm{H}_{2} \mathrm{O}$ & $\mathrm{CH}_{3} \mathrm{COOH}$ & 10 & 95 & 20 \\
2 & $\left(\mathrm{NH}_{4}\right)_{6} \mathrm{Mo}_{7} \mathrm{O}_{24} \cdot 4 \mathrm{H}_{2} \mathrm{O}$ & $\mathrm{EtOH}$ & 15 & 95 & 44 \\
3 & $\mathrm{CoCl}_{2}$ & $\mathrm{EtOH}$ & 300 & 59 & 44 \\
4 & $\mathrm{KHSO}_{4}\left(10 \mathrm{~mol}_{0}\right)$ & $\mathrm{EtOH}$ & 15 & 99 & 45 \\
5 & $\mathrm{ZnCl}_{2}$ & $\mathrm{EtOH}$ & 300 & 80 & 44 \\
6 & Magnetic material & EtOH & 3 & 95 & Present \\
\hline
\end{tabular}

Table 3. Synthesis of quinoxaline derivatives catalyzed by magnetic material ${ }^{\mathrm{a}}$

\begin{tabular}{ccccccc}
\hline \multirow{2}{*}{ Entry } & \multirow{2}{*}{$\mathrm{R}_{1}$} & \multirow{2}{*}{$\mathrm{R}_{2}$} & Time $(\mathrm{min})$ & Yield $(\%)^{\mathrm{b}}$ & Observed & M.P. \\
\hline $3 \mathrm{a}$ & $\mathrm{H}$ & $\mathrm{H}$ & 3 & 95 & $126-128$ & $126-127^{46}$ \\
$3 \mathrm{~b}$ & $\mathrm{H}$ & $\mathrm{NO}_{2}$ & 4 & 85 & $192-193$ & $193-194^{6}$ \\
$3 \mathrm{c}$ & $\mathrm{H}$ & $\mathrm{CH}_{3}$ & 3 & 90 & $116-118$ & $116-117^{6}$ \\
$3 \mathrm{~d}$ & $\mathrm{H}$ & $\mathrm{Cl}$ & 4 & 90 & $114-116$ & $115-116^{46}$ \\
$3 \mathrm{e}$ & $\mathrm{OCH}_{3}$ & $\mathrm{H}$ & 5 & 85 & $151-152$ & $151-152^{46}$ \\
$3 \mathrm{f}$ & $\mathrm{OCH}_{3}$ & $\mathrm{NO}_{2}$ & 4 & 85 & $190-191$ & $192-194^{47}$ \\
$3 \mathrm{~g}$ & $\mathrm{OCH}_{3}$ & $\mathrm{CH}$ & 4 & 90 & $128-130$ & $125-127^{46}$ \\
$3 \mathrm{~h}$ & $\mathrm{OCH}_{3}$ & $\mathrm{Cl}$ & 4 & 94 & $149-151$ & $150-151^{48}$ \\
\hline
\end{tabular}

${ }^{\mathrm{a}}$ Reaction conditions: 1 (5 mmol), 2 (5 mmol), $0.1 \mathrm{~g}$ magnetic material, $10 \mathrm{~mL}$ EtOH mechanically stirred; ${ }^{\mathrm{b}}$ Isolated yield

the catalyst in proportion to the initial amount of the reactants so as to complete the reaction in this stipulated time with the same yield. In order to present the merits of the present work in comparison with previously reported catalysts (Table 2), it is observed that magnetic material promotes the reaction more effectively than other catalysts.
The same reaction in the presence of other catalysts required longer reaction times for completion or the reaction works at higher temperature.

\section{Reusability of the Catalyst}

Catalyst reusability was tested using the o-phenylene- 


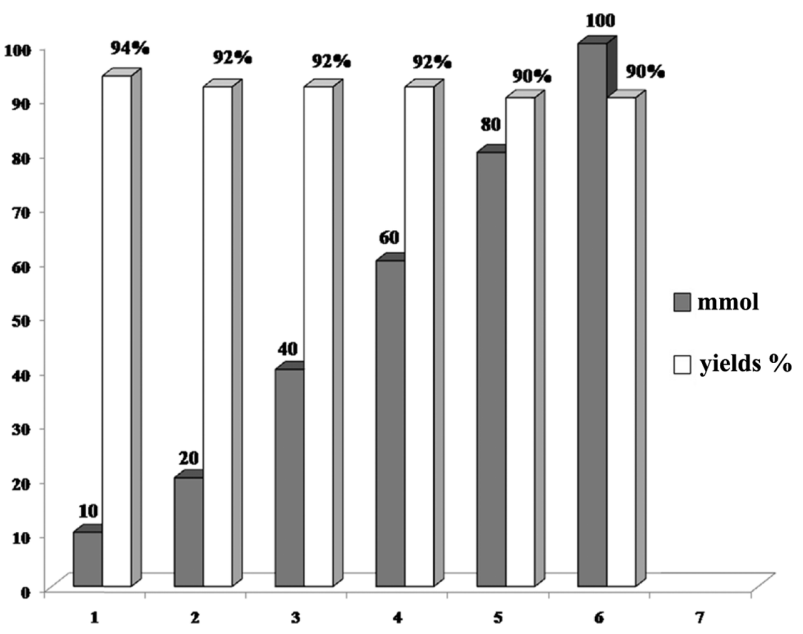

Fig. 8. \% yield of reaction on various mili mole of benzyl and O-phenyldiamine.

Table 4. Reusability of magnetic material for quinoxaline reaction ${ }^{\mathrm{a}}$

\begin{tabular}{ccc}
\hline Entry & Cycle & ${\text { Yield }(\%)^{\mathrm{b}}}^{\mathrm{b}}$ \\
\hline 1 & Fresh & 95 \\
2 & First & 94 \\
3 & Second & 94 \\
4 & Third & 94 \\
5 & fourth & 90 \\
\hline
\end{tabular}

$\overline{{ }^{a}}$ Reaction conditions $1(5 \mathrm{mmol}), 2(5 \mathrm{mmol}), 0.1 \mathrm{~g}$ magnetic material, $10 \mathrm{~mL}$ EtOH mechanically stirred; ${ }^{\mathrm{b}}$ Isolated yield

diamine ( $5 \mathrm{mmol})$ and benzil $(5 \mathrm{mmol})$ as model reaction. The catalyst was separated by simple filtration during the recrystallization, washed with $n$-hexane, dried at $60^{\circ} \mathrm{C}$ and activated at $120^{\circ} \mathrm{C}$ for $1 \mathrm{~h}$ and reused for the next run. The results are summarized in (Table 4), which reveals that, the catalyst could be used at least four times without significant loss in catalytic activity.

\section{CONCLUSIONS}

The present method describes a simple, efficient and eco-friendly method for the synthesis of various quinoxaline derivatives using magnetic material catalyst. Easy synthesis of catalyst, good stability at working temperature, simple handling, convenient work-up procedure, mild reaction conditions, versatility, recyclability inexpensive and eco-friendly nature of the catalyst, made this method a valid contribution to the existing methodologies. The catalytic material is easily obtained from the waste of power plants and proved to be efficient catalyst on the basis of conversion of reactants to products, this observation can be used to understand the cost effectiveness of the reaction.
Acknowledgments. The authors are grateful to UGC New Delhi for financial assistancs through SAP scheme and the Head, Department of chemistry, Dr.Babasaheb Ambedkar marathwada university, Aurangabad for providing the laboratory facility

\section{REFERENCES}

1. Islami, M. R.; Hassani, Z. ARKIVOC 2008, 15, 280.

2. Ghosh, P.; Mandal, A. Advances in Applied Science Research 2011, 2, 255.

3. Lindsley, C. W.; et al. Bio org. Med. chem. Lett. 2005, 15, 761.

4. Loriga, M.; piras, S.; Sanna, P.; Paglietti, G. Farmaco Societa Chimica Italiana 1997, 52, 157.

5. Seitz, L. E.; Suling, W. J.; Reynolds, R. C. J. Med. Chem. 2002, 45, 5604.

6. Jaung, J.-Y. Dyes and Pigments 2006, 71, 245.

7. Dailey, S.; Feast, W. J.; Peace, R. J.; Sage, L. C.; Till, S.; Wood, E. L. J. Mater. Chem. 2001, 11, 2238.

8. Crossley, M. J.; Johnston, L. A. Chem. Commun. 2002, 1122.

9. Sascha, O.; Rudiger, F. Synlett. 2004, 1509.

10. Yb, K.; Yh, K.; Jy, P.; SK, K. Bio Org. Med. Chem. Lett. 2004, 14, 541.

11. Hui, X. Desrivot, J. Bories, C. Loiseau, P. M. Franck, X. Hocquemiller, R. Findadere, B. Bio Org. Med. Chem. Lett. 2006, 16, 815 .

12. Mohammad, R. I.; Zahra, H. O. ARKIVOC 2008, 15, 280.

13. Woo, G. H. C.; Snyder, J. K.; Wan, Z. K. Heterocycl. Chem. 2002, 14, 279.

14. Brown, D. J. Quinoxalines: Supplement II. In The chemistry of Heterocyclic Compound; Taylor, E. C.; Wipf, P., Ed.; Wiley: New Jersey, 2004.

15. Bhosale, R. S.; Sarda, S. R.; Ardhapure, S. S.; Jadhav, W. N.; Bhusare, S. R.; Pawar, R. P. Tetrahedron Lett. 2005, 45,7183 .

16. Antoniotti, S.; Dunach, E. Tetrahedron Lett. 2002, 43, 3971.

17. Zhao, Z.; Wisnoski, D. D.; Wolkenberg, S. E.; Leister, W. H.; Wang, Y.; Lindsley, C. W. Tetrahedron Lett. 2004, 45, 4873.

18. Raw, S. A.; Wilfred, C. D.; Taylor, R. J. K. Org. Biomol. Chem. 2004, 2, 788.

19. More, S. V.; Sastry, M. N. V.; Yao, C. F. Green Chem. 2006, 8, 91.

20. Heravi, M. M.; Taheri, S.; Bakhtiari, K.; Oskooie, H. A. Catal. Commun. 2007, 8, 211.

21. Huang, T.; wang, R.; Shi, L.; Lu. X. Catal. Commun. 2008, 9, 1143.

22. Srinivas, C.; kumar, C. N. S. S. P.; Rao, V. J.; Srinivasan, P. J. Mol. Catal. A: Chem. 2007, 265, 227.

23. Belardi, G.; Massimilla, S.; Massimilla, L. P. Resour. Conserv. Cycle. 1998, 24, 167.

24. Blanco, F.; Garcia, M. P.; Ayala, J. Fuel 2006, 85, 2018.

25. Yamada, K.; Haraguchi, K.; Gacho, C. C.; Wongsiri, B. 
P.; Pena, M. L. Removal of Dyes from Aqueous Solution by Sorption with Coal Fly Ash. In Proceedings of the International Ash Utilisation Symposium; Lexington, Kentucky, U.S.A. 2003, p 22.

26. Cohen, H.; Lederman, E.; Werner, M.; Pelly, I.; Polat, M. Synergetic Effect of Coal Fly Ash as a Scrubber to Acidic Wastes of the Phosphate Industry. In Proceedings of the International Ash Utilisation Symposium; Lexington, Kentucky, U.S.A. 2003, p 20.

27. Zhang, A. L.; Deng, F. F.; Zhou, J. T.; Jin, R. F.; Ling, L. L.; Zhang, G. L. Huan Jing Ke Xue. 2009, 7, 1942.

28. Ghaffar, A.; Tabata, M. React. Kinet. Catal. Lett. 2009, 97, 35.

29. Gopalakrishnan, M.; Sureshkumar, P.; Kanagarajan, V.; Thanusu, J.; Govindaraju, R. A. ARKIVOC 2006, 13, 130.

30. Khatri, C.; Rani, A. Fuel. 2008, 87, 2886.

31. Dai, Q.; Lam, M.; Swanson, S.; Rachel Yu, R.-H.; Delia, J.; Milliron, Topuria, T.; Jubert, P.-O.; Nelson, A. Langmuir 2010, 26, 17546.

32. Kimura, T. Micropor. Mesopor. Mater. 2005, 77, 97.

33. Henry, N. F. M.; Lipson, J.; Wooster, W. A. The Interpretation of x-ray Diffraction Photographs; Macmillan: London, 1951.

34. Wensheng, L.; Shen, Y.; Xie, A.; Zhang, W. J. Magnetism and Magnetic Mater. 2010, 322, 1828.

35. Deng, X.; Lee, J.; Matranga, C. Surface. Sci. 2010, 604,
627.

36. Cristina, F.; Diniz, A. P. P.; Viana, N. Mohallem, D. S. J. Sol-Gel Sci. Tech. 2005, 35, 115.

37. Zhao, L.; Yang, H.; Cui, Y.; Zhao, X.; Feng, S. J. Mater. Sci. 2007, 42, 4110.

38. Mishra, B. G.; Rnga Rao, G. Bull. Mater. Sci. 2002, 25, 155.

39. Bezrodna, T.; Puchkovska, G.; Shimanovska, V.; Chashechnikova, I.; Khalyavka, T. Baran, J. Appl. Surf. Sci. 2003, 214, 222.

40. Akcay, M. J. Mol. Struct. 2004, 694, 21.

41. Seddigi, Z. S. React. Kinet. Catal. Lett. 2001, 73, 63.

42. Herrero, J.; Pajares, J.; A Blanco, C. Clays and Clay Minerals 1991, 39, 651.

43. Ravichandran, J.; Sivasankar, B. Clays and Clay Minerals 1997, 45, 854.

44. Hasaninejad, A.; Zare, A.; Mohammadizadeh, M. R.; Karami, Z. J. Iran. Chem. Soc. 2009, 6, 153.

45. Hossein, A.; Oskooie, Majid, M.; Heravi, K.; Bakhtiari, Taheri, S. Monatshefte Für Chemie 2007, 138, 875.

46. Niknam, K.; Saberi, D.; Mohagheghnejad, M. Molecule 2009, 14, 1915.

47. Heravi, M. M.; Tahrani, M. H.; Bakhtiari K.; Oskooie, H. A. ARKIVOC 2006, 14, 16.

48. More, S. V.; Sastry, M. N. V.; Yao, C. F. Green Chem. 2006, 91. 